Fall 1998

\title{
The Jewish Question in Eighteenth-Century France
}

Ronald Schechter

College of William and Mary, rbsche@wm.edu

Follow this and additional works at: https://scholarworks.wm.edu/aspubs

Part of the European History Commons

\section{Recommended Citation}

Schechter, Ronald, The Jewish Question in Eighteenth-Century France (1998). Eighteenth-Century Studies, 32, 84-91.

https://scholarworks.wm.edu/aspubs/781

This Article is brought to you for free and open access by the Arts and Sciences at W\&M ScholarWorks. It has been accepted for inclusion in Arts \& Sciences Articles by an authorized administrator of W\&M ScholarWorks. For more information, please contact scholarworks@wm.edu. 
A Jewish Agent in Eighteenth-Century Paris: Israël Bernard de Valabrègue
Ronald Schechter, The College of William and Mary

In Lettres orientales, an unfinished novel from 1754, the Arab merchant AbenZaïd writes from Constantinople to two friends: A Turk named Zadé and a Frenchman, the Chevalier de ***. Following the conventions of the epistolary novel, an "editor" introduces the correspondents. We learn that Aben-Zaïd is a "learned Oriental" who has grown wise through his travels. Although characterized by a "phlegmatic Asian temperament," Aben-Zaïd is amused by "stories, fables and accounts," which he enjoys sharing with his friends.

In the first letter, Aben-Zaïd writes Zadé of his arrival in Constantinople, "the residence of the most powerful prince in the world," Sultan Mahmud. After reflecting on the vicissitudes of Turkish history, he complains of the time that business has taken from his studies. "You know, dear Zadé," he writes, "my taste for languages, literature and the sciences, you know how I regret the time I am forced to give to my commerce." Nevertheless, Aben-Zaïd has managed to collect books from throughout Europe and to take many of them along on his voyages. Recently he has devoted his attention to a great book of the Jews: the Targum Sheni, the Chaldean paraphrase of the book of Esther.

Before discussing the book in detail, Aben-Zaïd asks Zadé if he remembers a lecture that they had both attended at the Academy of Science and Literature. The 
speaker, Lebeuf ${ }^{1}$, was discoursing on antique statues representing Pédauque, the queen with goose feet. He claimed that Queen Pédauque was identical to the Queen of Saba who had traveled to Jerusalem to admire King Solomon. Aben-Zaïd writes that the Targum Sheni provides evidence for Lebeuf's argument and, moreover, confirms what is written in "our divine Alcoran."

Aben-Zaïd writes that, according to the Chaldean paraphrast, King Solomon understood the languages of animals and was particularly proficient in those of all species of birds. During a festival a wild cock, which the paraphrast called Tarnegol Bara and is known as Houdhoud ${ }^{2}$ in the Qur'an made himself disappear. Some days later he reappeared and Solomon berated him for having taken leave without permission. Tarnegol Bara [the name Aben-Zaïd regularly uses] prostrated himself before the king and explained his absence. He had traveled the world "to see if I could not discover some country, province or kingdom that was unknown to Your Majesty, and which was not subject to your laws." After an exhaustive and fruitless journey, Tarnegol Bara was on the point of killing himself, but at that moment a bird of his species called his name. Heaven had sent him a "comforter," and the two birds swore eternal friendship.

Tarnegol Bara told his comforter of "Your Majesty, to whom I have the honor of belonging," depicting "with the most lively and natural colors your grandeur, your prudence, your wisdom, your riches, your beauty, your science, and the power which you exercise over all the Princes of the earth, who recognize themselves as vassals and who

\footnotetext{
${ }^{1}$ Abbé Jean Lebeuf (1687-1760) was an historian and hagiographer who used statues and monuments as well as manuscripts in his research.

2 The bird referred to is the hoopoe. Qur'an, Sura 27.
} 
pay you tribute, as to their Suzerain." The comforter replied with a description of his own country. He lived in "the most beautiful climate in the world," where the soil yielded an abundance of gold and silver. "These precious metals," he assured Tarnegol Bara, were "more common than dust." The trees dated from the creation of the world, and "the water of terrestrial Paradise was the only one drunk there." Throughout the country "a profound peace reigned"; its inhabitants did not know how to use arrows and the word "war" did not even exist. The sovereign of his utopia was the Queen of Saba, who herself was "one of the wonders of the world, for her beauty, her grace, her charms, her wisdom, in a word for all the qualities of the mind and the body."

Tarnegol Bara begged Solomon to pardon him for leaving without permission, promising in return to fly to Ethiopia to demand tribute. At this point Aben-Zaïd interrupts the tale to speculate that Saba, a land whose location was disputed, was in fact Ethiopia, not "Arabie Heureuse" (i.e. Yemen), as some maintained. He notes that the emperor of Ethiopia, Prester John, claims to descend from "the race of David by Solomon" and that "the Abyssinian women of quality boast of descending from the queen [of Saba], who made the voyage to Jerusalem to see Solomon."

After leaving the reader wondering about the fate of Tarnegol Bara, the "editor" provides a second letter from Aben-Zaïd to Zadé. Aben-Zaïd informs his friend that the bird's appeal succeeded. Solomon pardoned Tarnegol Bara and expressed a strong desire to see the fabled queen. He wrote a letter - which he tied to the cock's wing - inviting her to Jerusalem, where she would be received with all the honors that her high rank merited. Her counselors advised her to refuse, but when she heard what Tarnegol Bara had to say about Solomon - she understood bird languages too - she felt "an ardent desire 
to see and meet this king." She sent him a fleet accompanied by slaves and filled with perfumes, pearls, diamonds "and other precious things." Three years later she arrived in Jerusalem and became one of Solomon's many wives. Before the marriage, however, Solomon discovered that the queen had the feet and legs of a goose. He had his magicians remove the feathers from her legs and convert her and after consummating the marriage sent her back, pregnant, to her native land. She gave birth to Menilek, or Prester John, the first in a long line of Ethiopian kings. ${ }^{3}$

At this point, at the end of the second letter, the novel breaks off. There are no letters to the Chevalier de ${ }^{* * *}$, no responses from either of Aben-Zaïd's correspondents, no additional observations by the Arab merchant in Constantinople. The author had intended to publish the book in bi-weekly installments to subscribers at 15 sols per issue, but only the first, consisting of the two letters described above, ever appeared. In some ways the fragment of Lettres orientales is unremarkable. It was not unusual for a serial novel to remain unfinished, whether because of a lack of subscribers or for some other reason. Furthermore, the letters that were published have little literary value, if value is to be measured in originality. More than three decades earlier, in his enormously popular and much imitated Lettres persanes, Montesquieu had established the convention of basing a novel on the correspondence of an "Oriental." 4 More recently, the Lettres juives of the Marquis d'Argens, largely forgotten to posterity but a monumental success at the time, featured a highly educated merchant in Constantinople - in this case a Jew - and his

\footnotetext{
${ }^{3}$ Lettres orientales (Thessaloniki [actually Paris], 1754).

${ }^{4}$ Charles-Louis de Secondat, baron de Montesquieu, Lettres persanes
}

(Amsterdam, 1721). 
Jewish correspondents. ${ }^{5}$ Yet if the literary merits of Lettres orientales are doubtful, as a historical document the abortive epistolary novel is extremely valuable. It provides a window onto the mentality of the most neglected subject in eighteenth-century Jewish history: the Parisian Jew. It's author was a Jew named Israël Bernard de Valabrègue. Had he finished his work, it would probably have been the first French novel written by a Jew. It is in any case probably the first work of fiction, fragmentary though it is, published by a Jew in France. As such it provides, when contextualized, a rare look into the mind of a Parisian Jew. Whereas the official Jewish communities, or nations, as they were called, have received scholarly attention, the Jews who lived in a state of precarious semi-legality in Paris have not received significant scholarly attention in more than a century. Their story, however, and Valabrègue's in particular, is important not only for the history of the Jews, but for the history of the modern individual.

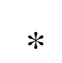

Valabrègue is not unknown to Jewish historians, but he has been discussed only in passing. The only scholarship that I have been able to find regarding him is a 14-page

\footnotetext{
${ }^{5}$ Lettres juives, ou Correspondance philosophique, historique \& critique, Entre un Juif Voyageur à Paris, \& ses Correspondans en divers endroits. Nouvelle édition augmentée de XX Nouvelles Lettres, de Quantité de Remarques, \& de plusieurs Figures (La Haye, 1738). On the popularity of Lettres juives see Ronald Schechter, Obstinate Hebrews: Representations of Jews in France, 1715-1815 (Berkeley: University of California Press, 2003), 43-44.
} 
pamphlet, written in 1914 by Paul Hildenfinger, sketching his life and listing the titles in his library, an inventory of which had been taken at Valabrègue's death. Thanks to Hildenfinger we know some important biographical facts and, crucially, the contents of his library, which contained 1792 volumes and was worth an estimated 1398 livres. Hildenfinger reports that Valabrègue was 35 when in 1749 he became "interpreter of oriental languages" at the Royal library in Paris. Valabrègue did not have to work daily at this job, which nevertheless paid 700 livres per year, more than twice the annual wage of a master artisan. ${ }^{6}$ While at the library he wrote catalogue cards for books in Semitic languages, but he had other occupations as well. He was a businessman who owned a license to sell silk and lace, and he was the "agent," or lobbyist, for the Jews who hailed from the papal enclave of Avignon (as did he) but now lived in Paris or Bordeaux. He also seems to have spent a good deal of time reading at home, if his extensive library is any indication. In addition to Scripture and rabbinical writings, he owned works by Homer, Montaigne, Cervantes, Corneille, Buffon and Voltaire. ${ }^{7}$

Other facts about Valabrègue's life can be gathered from various primary and secondary sources. Contemporary sources, about which I will have more to say, suggest that Valabrègue was also a lay religious leader for the Avignonese Jews residing in Paris, who gathered for services in his home on the Rue de Seine. Frances Malino, in her superb book on Valabrègue's successor at the Royal Library, notes that the famous

${ }^{6}$ Peter Sahlins, Unnaturally French: Foreign Citizens in the Old Regime and After (Ithaca: Cornell University Press, 2004), 106.

${ }^{7}$ Paul Hildenfinger, La bibliothèque de Bernard de Valabrègue (Paris: Librairie Henri Leclerc, 1911). 
Palestinian rabbi Azulai thought little of Valabrègue's qualifications. Azulai may have had Valabrègue in mind when he complained in his travel log of "scholars who drank wine in taverns and communal leaders with flexible views of Jewish law." ${ }^{8}$ He was more explicit, referring to Valabrègue by name, when he wrote, "He considers himself a rabbi, casuist, poet and learned in all the sciences," adding dismissively, "He knows the names." Azulai reported having been visited by Valabrègue three evenings in succession. On the first evening Valabrègue "praised himself as a scientist." On the second he boasted of a trip to Amsterdam, presumably for scholarly purposes. On the third he noted that women wrote him and "academies consulted him." ${ }^{9}$ He also seems to have had some trouble with the police. According to Israel Lévi, writing at the turn of the twentieth century but basing his claims on eighteenth-century police reports, Valabrègue was denounced for not having an up-to-date visa. This is quite plausible, given that Jews residing in Paris had to renew their visas every three to six months. Equally plausible under a system so prone to corruption was Valabrègue's own claim that Legrand, an inspector of police, took bribes. Another police inspector, Buhot, wrote of Valabrègue, "He is considered a usurer in the business that he conducts." ${ }^{10}$

Yet there is reason to believe that Valabrègue also worked as a police spy. According to a document in the archives of the Bastille, in February 1753 the police had "recourse to the services of Bernard de Valabrègue, interpreter," in the arrest of Joseph

${ }^{8}$ Frances Malino. A Jew in the French Revolution: The Life of Zalkind Hourwitz.

(Malden, Mass.: Blackwell. 1996), 56.

${ }^{9}$ Malino, 63, 231n.

${ }^{10}$ Revue des études juives 26 (1893): 297; and REJ 49 (1904): 123. 
Petit of Bordeaux for living in Paris without a visa. ${ }^{11}$ Were Valabrègue's "services" compensation for police connivance at his own violations of the law? Did they constitute a sort of plea bargaining? Did Valabrègue have a grudge against Joseph Petit? One can only speculate about these questions. One thing is certain. Valabrègue's relations with the police were turbulent. It is perhaps for this reason that Valabrègue, as we know from Peter Sahlins' masterful book on citizenship in pre- and post-revolutionary France, applied for letters of naturalization for himself and his family, a lengthy and expensive process which could cost roughly a year's salary at the Royal Library for each letter. Due to the ambiguous legal status of Jews under the Old Regime - they were tolerated residents but not unequivocally "subjects" - personal letters of naturalization could provide additional protection from the crown. Valabrègue's status was complicated by the fact that he had been born in the foreign city of Avignon. The Papal municipality passed back and forth between the Pope and the French crown, and from 1768 to 1774 it was French territory. After 1774, however, Valabrègue became a foreigner again. It was probably around this time that he began the slow process of naturalization, as he and his family received their letters in $1776 .{ }^{12}$ Valabrègue was in his 60 s at the time and was no doubt also thinking about his legacy. Foreigners and, according to some interpretations of the law, Jews as well, were subject to the droit d'aubaine, a law according to which

${ }^{11}$ Archives de la Bastille, 11844, dossier Worms. 1753. Cited in Bernhard Blumenkranz, Documents modernes sur les Juifs XVIe-XXe siècles (Paris: Commission Française des Archives Juives, 1979), 438.

12 Sahlins, Unnaturally French, 164. 
foreigners' estates were subject to confiscation upon their death. Letters of naturalization provided bearers the right to bequeath their fortunes.

Clearly Valabrègue knew how to take care of himself and his family. As "agent" of the Avignonese Jews in Paris, moreover, he was responsible for others as well. In order to understand this position, it is necessary to know something about the legal situation of the Jews in France. Expelled by Charles VI in 1394, the Jews were never formally readmitted to France but some were allowed to reside in specific localities and under very restricted conditions if they could demonstrate their usefulness and loyalty to the kingdom. In principle, they were banned from Paris, as they were from all cities in France except Bordeaux, Metz, and the periodically-French cities of Nancy (until 1766 capital of the duchy of Lorraine) and Avignon. ${ }^{13}$ Yet exceptions were made for merchants and their families who were considered useful to the kingdom. Most of the 40,000 Jews in France were relegated to villages in Alsace, which France had recently acquired from the Holy Roman Empire along with its Jewish populations and the customary laws that governed their existence. Each of the three principal Jewish groups - the Ashkenazim of the northeast, the Sephardim of the southwest, and the Avignonese

${ }^{13}$ The term "Avignonese" was applied to Jews from the Papal towns of Carpentras, Cavaillon, Isle-sur-Sorgue as well as Avignon. Sephardic and Avignonese Jews were also tolerated in small numbers in Saint-Esprit, just outside the Basque city of Bayonne. 
from the papal lands of Provence - had an agent or lobbyist in Paris who could plead the cause of his constituents through well-connected individuals in the city and at the court of Versailles. As Jews held only the rights - or more precisely, the privileges - that the king accorded in revocable Letters Patent and informal understandings, an agent was necessary to safeguard and, if possible, to increase them. Accordingly, he had to show that his coreligionists were useful and patriotic.

Approximately 500 Jews resided in Paris at any one time, about 100 of whom were Avignonese. Valabrègue's job was to portray them in a positive light. In 1765 he took an illness in the royal family as an occasion for doing precisely this. When the dauphin fell ill that year, individuals and corporate groups throughout France did what they typically did whenever a member of the royal family was ailing. They prayed publicly for the recovery of the afflicted person. Michèle Fogel has insightfully called such events "ceremonies of information." ${ }^{14}$ In a society that possessed few means of disseminating "the news," festivals in which participants prayed for recovery, mourned illnesses, celebrated royal births and military victories or otherwise responded to significant events functioned as a means of relating the latest information - of course with an official spin. This is a persuasive interpretation of such festivals, but there was another side to them. The celebrants themselves, usually in corporate groups with negotiable privileges, could use the occasions as a means of publicizing their patriotism.

${ }^{14}$ Michèle Fogel, Les Cérémonies de l'information dans la France du XVIe au milieu du XVIIIe siècle (Paris: Fayard, 1989). 
Like their gentile neighbors, Jews engaged in public prayers of thanksgiving, mourning or supplication, depending on the occasion. ${ }^{15}$ Upon word of the dauphin's illness, Jews in the tolerated communities held special services, chanted hymns composed for the occasion, and sent printed versions of their devotion to officials. ${ }^{16}$ Whereas most

15 Schechter, Obstinate Hebrews, 131-45.

${ }^{16}$ Déliberation conclue dans l'assemblée générale des syndics et communautés des Juifs de Metz, pour les prières publiques et extraordinaires, composées par les rabins et syndics, et ordonnées être dites soir et matin après dix-huit Pseaumes de David, pour obtenir de Dieu le recouvrement de la santé de Monseigneur le dauphin, la conservation de celle de Sa Majesté Louis XV, Roi de France et de Navarre, celle de Sa Majesté la plus pieuse des reines, et celle de la très-auguste famille royale. Metz, [1765]; David Athias, "Priere que les Juifs portugais de Bordeaux ont faite, pour demander à Dieu le rétablissement de la santé de Monseigneur le dauphin, le 21 novembre 1765, jour auquel ils se sont abstenus de toutes sortes d'affaires, ont fait des aumônes publiques, et ont observé un jeûne général de vingt quatre heures. Composée en hébreu par leur rabin, le Haham David Athias, et traduite en françois par le sieur P...... leur agent à Paris, pensionnaire et interprête du roi." Mercure de France 2 (January 1766): 82-87; Juda David Crémieu and Moïse de Roque-Martine, Prière faite par les Juifs du ComtéVenaissin, pour demander à Dieu, la guérison de Monseigneur le dauphin; composée par les Rabbins Juda David Crémieu, l'aîné, et Moïse de Roque-Martine, de Carpentras; traduite litteralement de l'hébreu. N.p., [1765]; Prière faite par les Juifs portugais du Bourg Saint-Esprit lès-Bayonne, au sujet de la maladie de Monseigneur le dauphin, fils unique du Roi Louis XV. Traduite de l'hébreu. N.p., [1765]. 
demonstrations of Jewish patriotism took place in provincial locations, Valabrègue had the luxury of displaying this trait in the center of Paris. Such was the public attention on the occasion that the Jesuit journal, Mémoires de Trévoux, published an account. On 14 November 1765, "having learned that public prayers had been prescribed" for Catholics in the archdiocese of Paris, and "wishing to join their prayers to those of the other Subjects of the King," the "Jewish residents of Paris" convened at Valabrègue's home on the rue de Seine. There they prayed for three hours and maintained a "steady and solemn fast following their custom." "Each Jew" made an offering of money to be used in purchasing the release of "a certain number of Christian prisoners from different prisons in Paris." This act of charity required official permission, so "the Jews presented a petition to M. the Lieutenant général de Police." He in turn had to forward their request to Versailles. The request was honored, and "the Jews assembled on the 19th of the same month" at Valabrègue's home. There they recited their morning prayers "with the required solemnity." Valabrègue, "the Book of the Law in his hands, pronounced aloud in Hebrew the Prayer" that the editors printed at the end of the article. "This prayer was repeated three times, each of the three days at Vespers and Complines." By the third day enough money had been collected "for the release of forty Prisoners." For the following three days the Jews accompanied the prisoners in a procession from Valabrègue's residence to the Church of Sainte Geneviève "to be present at the services" for the dauphin's recovery. Afterwards they returned "in the same order each day to the rue de Seine, to the home of sieur Bernard [de Valabrègue], who had a crown distributed to each one for their subsistence during the course of their devotions." 
A French translation of the Hebrew prayer followed the description. (I have been unable to find the Hebrew original.) The following is my translation of two selections from this emotionally-charged text:

Sovereign Master of the world, God, Creator of the heavens and the earth, we prostrate ourselves before you, our hearts contrite, overwhelmed with sadness, fasting and penitent, with the books of your holy Law in our hands, in which are written the attributes of your mercy, which we implore, Oh Eternal One, and pray to you to multiply the effects of your goodness and your clemency, upon the person of the Son of our King, DAUPHIN DE FRANCE, who is afflicted with illness and lying on his deathbed...

Oh Eternal One, our God, listen now to the prayers and the supplications of your servants; shine the light of your face upon this broken-hearted people; Lord ... open your eyes, and pay attention to our consternation; see our pain; be sensitive to our tears: for we are not entrusting ourselves to your justice when we address our prayers to you, prostrate before your face; rather it is in view of the multitude of your mercies that we address our prayers on behalf of the Son of the King: receive them favorably, Oh Lord our God, and just as you sweetened the waters of Marah through the ministry of Moses; as you cured Miriam his sister, and Hezekiah, King of Judah; so cure, Oh Eternal One, the Son of the King; calm your anger, cast 
your eyes upon him; act and do not delay, for your name is invoked by the City and by your people.

Finally, the Mémoires de Trévoux included a French translation of the "daily prayer for the King":

Almighty God, you who give salvation to Kings and keep in your right hand their life and their health; you who give power to Princes: Lord our God, who delivered David, your servant, from the murderous sword and preserved him from the ambushes of his enemies; you who divided the Red Sea to make a passage, and who made a path through the rapid waters of the Jordan: Oh Eternal One, our God, exalt our King LOUIS LE BIENAIMÉ, XV, King of France and of Navarre: Oh Eternal One, King of Kings, accord him, by your bounties, a long and permanent life; preserve him from every sort of sorrow, pain and disquietude; may his reign be of long duration, may happiness follow all his enterprises, and my guide it always toward that which can contribute to his glory and satisfaction; shower, Lord, his Royal Family with every sort of prosperity and blessing; spread, by your infinite bounty, peace, joy and abundance in all corners of his Kingdom; preserve, Lord, in his heart the goodness and clemency 
whose effects we feel; may his ministers, in following his example, be favorable to us; your will be done. Amen. ${ }^{17}$

By translating this little-known feature of the Jewish liturgy, and by combining it with a prayer specially composed on the occasion of the dauphin's illness, Valabrègue defended his coreligionists from the common charge that they were disloyal or separatist. Compounding this effect was the series of processions in which Jews demonstrated their sympathy for and fraternity with Christians by liberating prisoners, accompanying them to church, and giving them charity. By taking them to the services at Sainte-Geneviève, moreover, Valabrègue showed his knowledge of Christian hagiography: Geneviève had famously liberated prisoners in Paris during the fifth century. It is also possible that the action of freeing prisoners reminded French observers of the restrictions that the Jews endured and their own need for emancipation, though their munificence may have contributed to the opposite message: that Jews were not suffering. These two messages, though contradictory, nevertheless constituted the template for explicit arguments in

17"Récit de ce que les Juifs résidens à Paris ont fait à l'occasion de la maladie de Monseigneur le Dauphin," Journal de Trévoux ou mémoires pour servir à l'histoire des sciences et des arts 66 (1766): 91-93; and Bernard de Valabrègue, Précis de la prière que les Juifs avignonois établis à Bordeaux, et ceux d'Avignon, actuellement à Paris, ont faite pendant trois jours consécutifs, [le 19 novembre 1765] pour obtenir de Dieu le rétablissement de la santé de Monseigneur le dauphin, extraite du rituel hébreux, et prononcée en cette langue, par le Sieur Bernard de Valabrègue, secrétaire-interprête du roi, et traduite par le même (n.p., [1765]). 
favor of lifting legal restrictions on the Jews and recognizing them as French. The Jews were useful by virtue of their wealth, but suffering due to legal discrimination. They should be emancipated although, and because, they were wealthy.

In 1767 Valabrègue reinforced the message that Jews were useful, loyal and undervalued. That year the government instituted a program allowing foreign merchants to purchase master's licenses without first working as apprentices and journeymen. When Valabrègue and four other Avignonese Jews purchased the new licenses as foreign merchants - Avignon would only become French the following year - the federation of Parisian merchant guilds known as the Six Corps objected to the Parlement of Paris. The merchants published their brief, thus initiating the sort of cause célèbre that Sarah Maza has shown to have captured the attention of the public in pre-revolutionary France. ${ }^{18}$ In addition to questioning the legality of considering Jews foreigners and hence eligible to take advantage of the government's incentive for foreign businessmen -- in a cynical reversal of the standard anti-Jewish claim that the Jews were eternal foreigners -- but it also repeated the vast repertoire of medieval accusations against the Jews and their religion, from charges of ritual murder and well-poisoning to the claim that Judaism

${ }^{18}$ Sarah Maza, Private Lives and Public Affairs: The Causes Célèbres of Prerevolutionary France (Berkeley: University of California Press, 1993). 
authorized usury against Christians. ${ }^{19}$ In response, Valabrègue wrote a 71-page pamphlet that not only defended the Jews' legal right to the licenses but refuted the claims of the Six Corps and served as an apology for Judaism and the Jews in general. ${ }^{20}$

For the purposes of his pamphlet Valabrègue posed as an English "milord" writing to his correspondent in Paris about the conflict between the Jews and the merchants' guilds, though he hinted at his identity by providing the initials "J.B.D.V.S.J.D.R" [Israël Bernard de Valabrègue, Secrétaire-Interprête du Roi]. The pamphlet begins as the English observer writes in praise of commerce, that "branch of human industry" which he claims to have practiced before the death of an elder brother made him a lord. "The more [it] occupies Citizens," he writes, the more commerce "become[s] useful to society," and he compares it to "those inundations of the Nile that fertilize the soil of Egypt." Following this allusion to the fabled East, the milord begins his discussion of the Jews. He has read the Parisian merchants' attack on the Jews and denounces the pamphlet as "the recapitulation of a multitude of ridiculous fables, invented during centuries of ignorance[,] but which should never reappear during an enlightened century."21

${ }^{19}$ Requête des marchands et négociants de Paris contre l'admission des Juifs. 1767; reprinted 1790 .

${ }^{20}$ [Israel Bernard de Valabrègue], Lettre ou réflexions d'un milord à son correspondant à Paris, au sujet de la requête des marchands des six corps, contre l'admission des Juifs aux brevets (London, 1767),

${ }^{21}$ Lettre d'un milord, 5-6. 
Despite the author's invocation of Enlightenment and the distance he appears to establish between his own century and those of prior generations, he justifies the Jews' rights largely by invoking historical precedent. The pamphlet consists chiefly of a recounting of Jewish history from antiquity to the present, with an emphasis on the tradition of state tolerance for a people that repeatedly proved itself useful. With a learned reference to the Codex Theodosianus, the author notes that Emperor Honorius protected the Jews out of the conviction that "the glory of a prince consists in letting each society enjoy in tranquility the rights that it has acquired," and that "even when a religion is not approved by a sovereign, he must preserve its privileges." ${ }^{22}$ Similarly, Pope Gregory the Great, though not approving of Judaism, nevertheless treated its devotees well. Louis the Pious accorded them many privileges, Gregory IX protected them and anathematized their persecutors, and Pope Innocent IV defended the Jews against blood libels. Elsewhere the author catalogues the countries in which Jews are well treated, dates the origins of their privileges and praises the relevant sovereigns for their wisdom in recognizing the utility of a Jewish population.

The vague allusion to "persecutors" suggested that not all sovereigns treated the Jews well, but insofar as Valabrègue sought to establish the tradition of tolerance he needed to deemphasize the unhappy chapters of Jewish history. Past persecutions are downplayed, as in the following passage, where the author praises Henri II for accepting Jews in Bordeaux without mentioning their recent expulsion from Spain and Portugal:

\footnotetext{
${ }^{22}$ Lettre d'un milord, 20, 21.
} 
Henri II knew how essential it was for him to increase the springs of commerce in his states. This would contribute to the well-being of his subjects and to his own resources. He even knew that the industry of the French still needed to be enlightened by examples. The PortugueseJewish merchants appeared. This prince welcomed them. ${ }^{23}$

Whence the merchants "appeared" goes unmentioned, as Valabrègue moves ahead in history. The Letters Patent that Henri II accorded the merchants in 1550 proved "extremely useful" to the state in their stimulation of trade, and Henri III renewed them accordingly in 1574 . Louis XIV, instructed by Colbert in the importance of trade, confirmed the privileges of the Portuguese in 1658, and Louis XV followed suit in 1723.

Just as he highlights the history of toleration accorded the Jews, Valabrègue emphasizes their geographical dispersion in his own day, taking this as a sign that rulers appreciate their value. He writes, "I have traveled, and I have hardly seen any country in Europe, Asia or Africa where the Jews are not received." ${ }^{24}$ He writes sanguinely of their freedom of religion and commerce in Poland, Germany, Italy, Ottoman Europe, and he is particularly impressed with their situation in England and the Netherlands. He improbably claims that 80,000 Jews live in Amsterdam and that they constitute a powerful presence at The Hague. "It is there [in the Netherlands]" he writes, "that the rich of the [Jewish] Nation assemble and come to enjoy in tranquility the treasures that

\footnotetext{
${ }^{23}$ Lettre d'un milord, 8, 9.

${ }^{24}$ Lettre d'un milord, 51.
} 
they have amassed. It is there that they shine with their prosperity, their luxury and their superb buildings."

All this they do without arousing the jealousy of Christians. Why? Because the Jews enrich the countries in which they are given broad liberties. Valabrègue claims that since admitting the Jews in the previous century, England has seen its trade increase by 50 percent. The settling of Jews in Holland prompted a two-thirds increase in that country's trade. Valabrègue reports similar gains for the cities of Hamburg and Leghorn, and predicts that France's trade would "be tripled or quadrupled" if Jews were given unrestricted trading privileges. ${ }^{25}$

In order to explain the relationship between the presence of Jews in possession of extensive liberties and the increased wealth of states, Valabrègue had recourse to the widespread belief in the Jews' special aptitude for commerce. The author quotes Savary's Dictionnaire universel, "'The Jews have the reputation to be very capable in commerce.... It is certain that even the Nations most prejudiced against them not only suffer their presence among them, but even seem to be eager to learn from them the secrets of trade and to share in the profits therefrom."'26 He adds, "'They are very rich: they are involved in every type of commerce, particularly banking. The have very good

${ }^{25}$ Lettre d'un milord, 70, 71.

${ }^{26}$ Jacques Savary des Brulons, Dictionnaire de commerce, Valabrague cites a "Paris edition of 1756 [which I have been unable to find in the Bibliothèque Nationale de France], vol. 5, 442-443. Valabrègue owned an edition of the Dictionnaire. Hildenfinger, Bibliothèque, 14 
credit, whether for banking or for commerce in merchandise, within and without [the countries in which they live].'" Then, quoting the Encyclopédie, he writes:

"...dispersed in our day with the greatest security they have ever had in every country in Europe where commerce reigns, they have become instruments by means of which the most distant nations can converse and correspond together. They have become like the pegs and nails that one uses in a great building, and which are necessary to join all of its parts."27

This sort of idealistic cosmopolitanism, however, might easily have troubled more nationalistic readers - indeed the very readers who were susceptible to Valabrègue's suggestion that the French needed to catch up with countries that benefited more from Jewish commerce. If the Jews were the "pegs and nails" in a "great building" comprising the globe, what were they in relation to France? How could the French be sure that the Jews would not take the wealth they amassed in France to other countries? More generally still, the degree of prejudice against Jews in matters of business made it difficult to convince readers that Jews could make money without harming gentiles in the process.

Valabrègue was aware that opponents of the Jews might view them as all too skillful at business, and moreover prone to turn their skills against their Christian hosts.

${ }^{27}$ For the passage to which Valabrègue refers, see Encyclopédie, ou Dictionnaire raisonné des sciences, des arts et des métiers (Paris, 1751-1772), s.v., "Juif," vol. 9, p. 25. 
After all, anti-Jewish polemicists, among them the merchants of Paris, inevitably brought up the alleged Jewish propensity to profit from Christians' need for cash by lending to them at usurious rates. They often "explained" the vice of usury as sanctioned by the Old Testament, citing the verses in Deuteronomy, "You may not lend silver, nor grain, nor any other thing to your brother at usurious rates, but only to strangers." 28 In his refutation of this charge, Valabrègue skillfully cites the Christian commentator Don Calmet to demonstrate that the word "stranger" in the Biblical context referred only to the Canaanites, who were anathema and to be treated as enemies, and not to foreigners in general. He also quotes the gloss of St. Ambrose, who maintained that usury in Biblical times was "an act of hostility" and "a way of making war against" people whom one could "kill without crime," and that the early rabbis already forbade the exercise of this right. $^{29}$

The repeated claim that the Bible authorized usury toward non-Jews reflected a more general popular belief that the Jews were required by their law to hate all gentiles. The Six Corps claimed as much, and argued that such a hostile people could never engage in honest business with Christians. Again, Valabrègue turns to Christian commentators to refute the claim. Referring to the historian Basnage, he argues that the Jews regard Christians as Idumeans, or descendants of Jacob's brother Esau, and as such deserving of affection. He also cites Don Calmet's commentary on the prescription, "You shall not hate the Idumean, because he is your brother, nor the Egyptian, because you were

\footnotetext{
${ }^{28}$ Deut 23: 19, 20.

${ }^{29}$ Lettre d'un milord, 41.
} 
strangers in his land," as proof of the "generosity" and "appreciation" that Jews were required to feel toward their non-Jewish neighbors. ${ }^{30}$

Valabrègue uses the notion of "appreciation" not only to assuage fears of Jewish usury, but also to counter the claim that Jewish merchants, once established in France, would rob the country of its wealth and transport it abroad. He asks rhetorically, "Isn't it most ridiculous, isn't it a manifest absurdity to wish to convince people that [the Jews] would try to betray their patrie and their home? Wouldn't this be to destroy themselves? Does one pierce the breast of the mother who feeds us [sic]?" He predicts that "the land that nourishes them will become a new patrie for them," and asserts, "They will not be tempted to carry the riches away from [the land] to which they owe them." Finally the "milord" writes, "The Jews respect the laws of society, however imperfectly they benefit from them." He urges his correspondent, and the French more generally, "Let [the Jews] enjoy all the rights of citizens, [and] they will certainly have the soul of a citizen." 31

The Lettre d'un milord reflects the commercial nationalism of its day. As David Bell has shown, nationalism in France was not an invention of the French Revolution or the post-revolutionary period, as historians have commonly thought. The experience of the Seven Years' War (1756-1763) in particular had prompted French subjects to think of themselves as part of a French nation. ${ }^{32}$ Around this time, moreover, economists at midcentury began to think differently about what constituted a nation's economic interests.

${ }^{30}$ Lettre d'un milord, 61, 62.

${ }^{31}$ Lettre d'un milord, 69, 70.

32 David Bell, The Cult of the Nation in France: Inventing Nationalism, 16801800 (Cambridge, MA and London: Harvard University Press, 2001), esp. 78-106. 
For the past century the orthodoxy in political economy had been mercantilism, a doctrine epitomized by Louis XIV's minister Colbert and consisting of the belief that the highest priority for the state was to keep its level of specie higher than that of other countries. Valabrègue assumed this way of thinking in his readers when he anticipated the fear that Jews, once given the opportunity to make money in France, would take their wealth to other countries. Elsewhere he revealed his own mercantilist leanings, writing, "A country that has neither gold nor silver mines can only attract the one or the other [i.e. gold or silver] by means of commerce." This was where the Jews could be useful, as "commerce itself needs intelligent men with good credit, men who will dedicate themselves [to commerce] without reservations and who will raise their children in the same spirit." Valabrègue adds, "this would be the case of the Jews; it is not at all that of the majority of French businessmen." 33 French gentiles, he maintains, waste their wealth buying titles and military commissions for their sons, who in turn add nothing to the nation's wealth.

Like Abbé Coyer, a commercial nationalist who in his Nobless commerçante (1756) had also complained that the nobility's disdain for trade hurt the French economy and was therefore unpatriotic, Valabrègue connected contemporary noble culture with economic stagnation - though unlike Coyer, who hoped to turn the nobles into merchants, Valabrègue assumed that the stigma which the titled attached to trade was a fixed feature of the nobility's mentality. ${ }^{34}$ By the time Valabrègue was writing, however,

${ }^{33}$ Lettre d'un milord, 70.

${ }^{34}$ Coyer also complained that anti-Jewish prejudice damaged the French economy. Abbé [Gabriel François] Coyer, La noblesse commerçante (Paris, 1756), 72. 
and even during the decade in which Coyer wrote, mercantilism was losing its status as undisputed dogma. A new school of political economy, physiocracy, argued that commerce was sterile and that land was the principal source of wealth. Indeed, the competition between mercantilism and physiocracy is reflected in the very program that ignited the controversy to which Valabrègue's Lettre d'un milord contributed. Designed to increase commerce and improve the trade balance by attracting foreign traders to France, and hence in accordance with mercantilist thinking, the new program sought to diminish the power of the guilds, whose monopolistic grip on production had been encouraged under mercantilism but came under attack by the physiocrats.

Yet the decline of mercantilism was only one aspect of a larger shift in mentality away from a rationalistic, mechanistic view of the social world to one that was more romantic and organic. Although the original physiocrats were not teary-eyed about the soil, their valorization of the land resonated with a culture increasingly disposed to organic concepts and language. Mercantilism fit well into a Newtonian universe of calculability, and its vehicle, the rationalizing absolutist state with the power to regulate trading companies, served it well. Furthermore, the mechanistic anthropology of philosophes such as Condillac, La Mettrie, Helvétius and, to a certain degree, Voltaire, ${ }^{35}$ justified luxury, the sector of the economy most supported by a mercantilist regime, as a means toward the Enlightenment goal of increasing happiness. Materialistic in more than one way, the theories of knowledge associated with sensationalism rejected the

\footnotetext{
${ }^{35}$ On the mechanistic aspect of the Enlightenment, See Xavier Martin, The French Enlightenment and Human Nature: From the Enlightenment to the Napoleonic Code, trans. Patrick Corcoran (New York and Oxford: Berghahn, 2001.
} 
immaterial soul and made tactile pleasure the foundation of happiness. In such a philosophical environment, Valabrègue could expect sympathetic readers of his description of the Dutch Jews as people who "shine with their prosperity, their luxury and their superb buildings." [57] And the Jews more generally could be described in architectural-engineering terms, as the "pegs and nails that one uses in a great building."

Around 1760, however, mechanism began to give way to organicism and sensationalism yielded to sensibilité, an aesthetic style and moral doctrine characterized by very un-Newtonian, that is unpredictable, and vaguely spiritual experience and behavior. Most famously associated with Rousseau, sensibilité emphasized virtue, a classical-republican quality at odds with the luxurious corruption of courts and cities. Republican virtue in turn required the ability to feel for others, and this sympathy, or fraternity, was an indefinable quality explicable only in terms of a soul communing with fellow-souls. This is why the greatest compliment one could receive in the nascent culture of romanticism was to be called une âme sensible - a sensitive soul. ${ }^{36}$

Ideally, an analogous relationship obtained between human beings and "nature." An unmediated love of the earth, itself an organism animated by a vitalist principle, gave the term "soil" an emotional charge. Together fellow-feeling and love of the land informed - and no doubt contributed to - a changing political climate out of which modern nationalism emerged. The sacralization of the nation - a mystical hybrid of land and people - came at the expense of a monarchy whose caché consisted more in the powerful rationalized state it managed than its officially-proclaimed union with God. It

${ }^{36}$ On the cult of sensibilité, see Simon Schama, Citizens: A Chronicle of the French Revolution (New York: Knopf, 1989), 145-62. 
is not a coincidence, in this respect, that the transition between rationalism and romanticism, mechanism and organicism, sensationalism and sensibilité, corresponded with the attack on "despotism" by magistrates claiming to represent the "nation" toward the end of the reign of Louis XV. Nor, for that matter, is it an accident that this new pathos would dominate in the Revolution.

This conjuncture of philosophy and politics was of crucial importance to Valabrègue's cause. Just one year before the Six Corps filed their case with the Parlement of Paris, that same judicial body had claimed the right to combine with the kingdom's other parlements and together to represent that increasingly-invoked but illdefined entity known as the nation. The king hit back with a séance de flagellation that reiterated the principles of absolutism, but he was defending a beleaguered political philosophy, one that appeared increasingly passé next to its republican competition. ${ }^{37}$ In this environment it was not enough to be useful or functional. One had to have a patriotic soul. Valabrègue seems to have absorbed this message, and he therefore promises that the Jews will be more than pegs and nails in an edifice. "Let them enjoy all the rights of citizens," he vows, and "they will certainly have the soul of a citizen."38

Commercial nationalism was of course, after all, nationalism. The point was to benefit the nation through trade. At the same time, it allowed for cosmopolitanism,

${ }^{37}$ For the "Session of the Scourging" see Keith Michael Baker, ed., The Old Regime and the French Revolution (Chicago and London: University of Chicago Press, 1987), 47-50.

38 “Laissez-les jouir de tous les droits des citoyens, ils auront à-coup-sûr l'âme citoyenne." 69 
indeed demanded it. By the 1760s, however, a new way of thinking about the nation, which one might usefully call geophilic nationalism, fetishized the soil and posited a mystical connection between the land and "its" people and among the people themselves. Geophilic nationalism was far more provincial than commercial nationalism, and the place of the Jews within this newly constructed social identity was unclear. Did they belong to the land? Centuries of legal discrimination had preventing them from becoming landowners, and their proverbial dispersion had made them cosmopolitan, at least in the eyes of gentile observers. Their famed isolation and alleged animosity towards Christianity made their sympathetic union with Christians doubtful. Indeed, in apologies for the Jews over the following two decades, whether penned by Jews or gentiles, would have to go beyond doctrinal distinctions between Canaanites and Idumeans. They would have to include the promise that Jews would love the patrie and its inhabitants and take advantage of any reforms that would allow them to work the sacred land of France. Valabrègue showed an understanding, conscious or unconscious, of this new kind of nationalism. Already in 1765 he had employed the language of sensibilité to show that the Jews wept in anguish over the dauphin's suffering. Now he invoked the mystical idea of the "soul of a citizen." His Lettre d'un milord, insofar as it employs both types of nationalism, sheds light on the hesitating migration from one distinct way of thinking about France to a very different one. 
Valabrègue and his Avignonese colleagues managed to keep their merchant licenses, in the midst of protracted litigation, until 1774, when the Parlement of Paris finally sided with the Six Corps. ${ }^{39}$ Ironically, it was during that same year that Avignon reverted from French to papal control, which in principle should have made the Avignonese "foreigners," as they had been in 1767, and thus eligible for the licenses, though this change in status did not change the verdict of the Parisian magistrates. Legal niceties aside, Valabrègue appears to have thought of himself as French. In 1765 he had referred to Louis XV as "notre monarque," and in 1774 he took steps to clarify his nationality by applying for French naturalization. The following year Valabrègue had one final opportunity to express his thoughts and feelings about his national identity: the coronation of Louis XVI.

On June 11, 1775, crowds packed into the cathedral at Reims to see the new king crowned. The ceremony included the monarch's anointing with the sacred oil that a dove had reputedly brought down from heaven for the christening of King Clovis nearly 1200 years earlier; it also featured the new "most Christian king" taking an oath "to extirpate heretics." Meanwhile, approximately 100 miles away, the Avignonese and Portuguese Jews residing in Paris gathered at the home of Israel Bernard de Valabrègue, where they held their own celebration. For the occasion Valabrègue had composed two odes in Hebrew, which he chanted with his coreligionists. Valabrègue used the word mizmor, meaning "song" or "poem," to describe his compositions, which were based loosely on Psalms 21 and 72.

${ }^{39}$ Arthur Hertzberg, The French Enlightenment and the Jews (New York: Columbia University Press, 1968), 56. 
The first mizmor is called a Psalm of David, and thus makes the same connection between the French sovereign and the anointed king of Israel that the sacred chrism of Clovis was meant to recall. It consists of fourteen quatrains, each of which is followed by the acclamation, yechi ha-melech, or "long live the king!" It begins with "my prayer for the king's salvation" and asks God to "raise up his [the king's] power over all cities and all their environs." This imperial mandate is reinforced by the image of strangers bowing before the king, and the worshippers warn potential enemies that the "hand of God" will find them, surround them, and "put them in the furnace of fire" until their bones become dry. "God's anger will swallow their carcasses," "fire will devour their souls," and their offspring will "disappear from this world."

The second mizmor recalls Psalm 72, titled "to Solomon" and particularly appropriate for a coronation celebration. It contains 18 quatrains, each followed by a "Halleluiah." Like the first mizmor, this one affirms the king's power as sustained by God. It is more precise, however, about the attributes of divine kingship. The first quality is justice [mishpat], a term that recurs frequently in the song. The congregation prays that the king will "do justice in all your [God's] ways," that he will "judge the wicked and the rebellious," while "the poor of the land and the sons of the poor he will save." He will sustain the poor, it is hoped, by providing wealth for his country. This wealth, Valabrègue implies, will come from empire. Thus the mizmor asks God, on the king's behalf, for a realm stretching "from sea to sea and to the end of the earth," an empire encompassing "desert dwellers" who "bow on their knees" and kings bearing gifts. Listed among the tribute-paying kingdoms are Saba - the fabulously wealthy land about which Valabrègue had written in his Lettres orientales - as well as "Tarshish and 
the islands," realms mentioned in Psalm 72 but perhaps now alluding to the island nation of Great Britain. ${ }^{40}$

Along with others living in France, Jews and Gentiles alike, Valabrègue wished to see Louis XVI rule over a vast empire, a poignant desire given the loss of imperial possessions to the British in the Seven Years' War. That such an empire might provide "tribute" for the French did not make this fantasy incompatible with patriotism. The dream of Solomonic wealth flowing into the ports was consistent with commercial patriotism as informed by mercantilist principles. Yet, as I have already suggested, another strand of nationalism emphasized the soil and its fruits. Psalm 72 provided symbolism consistent with this way of thinking as well. The mizmor accordingly entreated God to assure that "good grain will sprout up," the king's "fruit will grow high" like the cedars of Lebanon, his crops "will grow like grass," and the congregants prayed, "May there be a bit of field even on the mountaintops." Finally, Valabrègue's coronation song affirmed contemporary political culture by referring not only to the king and his realm, but to the "nation" or "people" as well. Thus the composer and his brethren intoned, "May he [the king] rule, may he judge your people in righteousness." In the original Psalm, "your people" [amcha] meant unequivocally the people of Israel, God's Chosen people, but on the occasion of Louis XVI's coronation the term had a more ambiguous meaning. Certainly Valabrègue wanted the king to treat the Jews justly, but did "your people" comprise the Jews, or rather the Jews and the gentiles of the kingdom?

${ }^{40}$ On the symbolic association of Tarshish and Great Britain see Schechter, Obstinate Hebrews, 136-7. 
And what was the relationship between the Jews and the French? The final stanza leaves these questions unanswered:

Blessed be the friend of God; blessed be our king,

He who does great wonders alone.

Sing, Oh people of Israel, to the glory of our protector.

Sing to God, whose glory fills the whole earth.

Halleluiah.

The term "our king" [malkenu] indicates a sense of Jewish belonging in the realm of the "friend of God," yet the vocative "Oh people of Israel" [am Yisrael] suggests a separation between the French and the Jews, and the notion of Louis as "our protector" [tsorenu] hints at the familiar arrangement according to which the worldly sovereign merely "protects" the Jews from the depredations of gentiles.

Though no doubt hopeful that Louis XVI would prove a friend of the Jews as well a friend of God [yedid Elohim], Valabrègue was no less attuned to the precarious situation of the Jews in France, and especially in Paris, than he had been in the past. He therefore took care to translate the mizmorim into French, thus publicizing his patriotism and that of the Jews for whom he served as "agent." He had the two versions published in a bilingual edition with the imprimatur of the censor at the Sorbonne. ${ }^{41}$ Like the

${ }^{41}$ Israel Bernard de Valabrègue, Odes prononcées par les juifs d'Avignon et de Bordeaux résidants à Paris, dans leur assemblée, à l'occasion du sacre de Louis XVI, le 11 juin 1775. Tirées du texte original des Pseaumes 20 et 71 (21 -- 72). Mises en vers 
Hebrew original, the translation is indefinite regarding the relationship between the Jewish and gentile "people" of France. "Amcha" becomes "ce Peuple chéri" ("this dear People)." The demonstrative "this" more plausibly refers to the French (not including the Jews) than the original "your people," though the adjective "dear" connotes an affinity between the two groups. The last stanza is even less clear about who is who:

Adressons tous à Dieu nos voeux et nos souhaits;

Que du Nom de LOUIS la Terre retentisse;

Et que l'Éternel le bénisse;

Que ses bontés pour nous ne s'altèrent jamais.

ALLELUIA.

hébreux, par M. Bernard de Vallabrège, interprète du roi, etc. Hebrew title: Kol rinah ve-kol todah u-tehilah nishma baveit tefilatanu poh paris ha-ir ha-gedolah be-k[ehila] $k$ [adosha] sfardim anshei avinion ve-bordeos yom asher nimshach u-nekater adoneinu ha-melech Luis ayin yud yar[om] h[odo] yud alef Sivan shanat heh tav kuf lamed heh hitkalah yatsirah ... ha-tsair yisrael bernard devalabregia sofer u-targman lemelech tsarfat yar [om] h[odo] [A song of joy and a song of thanks and praise heard in our house of prayer here \{in\} Paris, the great city, in the holy congregation of Sephardim, men of Avignon and Bordeaux, the day of the anointing and coronation of our lord the king Louis 16, may his splendor grow, 11 Sivan year 5535 of creation ... \{by\} Israel Bernard of Valabreghia junior, scribe and translator to the king of France, may his splendor grow.] (Paris, 1775). 
Let us turn all our prayers and wishes to God;

May the Earth resound with the name LOUIS;

And may the Eternal One bless him;

May his kindness for us never be impaired.

"Our protector" has become one who shows "bounties for us," though whether "us" indicates the Jews, the gentiles, or both is left vague. Nor does the possessive adjective "nos" ("our") specify a demarcation between the Jews and the surrounding French society. There is a sense of insecurity in the use of the reflexive verb "s'altérer," perhaps even a sense that the new king may be weak or fickle, that his kindness may be "impaired," but given the ambiguity of the word "nous," ("us") the Jews are not necessarily singled out in this scenario.

Ultimately, it is the printing of the Hebrew original side by side with the French translation that, more than any formulation in either version, draws a line between two peoples. To most French gentiles, the very appearance of Hebrew characters created an impression of foreignness. It served to assert the sincerity of the Jews' acclamation and their true patriotism - prevalent prejudice might have the Jews prone to insincerity, but not even the most anti-Jewish contemporaries ever accused them of lying to God - yet it simultaneously underscored Jewish difference. Valabrègue reinforced this sense of distinct Jewish and French identities by remarking on the difficulty of translating the songs from Hebrew into French. In a translator's note he acknowledged diverging from "the literal meaning of my Hebrew verses," and that he "less followed the successive ideas of the Hebrew strophes than wished to grasp their meaning in its entirety." Yet he 
justified his translator's license by noting that "it is a long way from a primitive and sacred language to the idiom of this country."

Ironically, this othering of the Jews through the "primitive" character of their "sacred" language served to add to their credentials as French citizens, at least when viewed through the lens of geophilic nationalism. Mercantile nationalism and the rationalism behind it valued neither the primitive nor the sacred. Its adherents would have been more impressed by the Solomonic, imperialistic imagery of the mizmorim. But the nationalism inspired by sensibilité exhibited misgivings about the reputed gifts of civilization and idealized a mythical "primitive" past when wealth did not come from ships laden with luxury merchandise but from a generous and fruitful earth. In this arcadian time human interaction was guided by feeling, not calculation. Paradoxically, though geophilic nationalism paved the way for the political revolution that would emancipate the Jews, its mistrust of rationalism created new problems for them. The Jews had a reputation for being highly skilled in calculation - both in the ordinary and pejorative sense - and the new political culture required fellow feeling. ${ }^{42}$ In this ethical environment the esprit calculateur was unnecessary at best and dangerous at worst. By associating Judaism with the primitive, therefore, Valabrègue defended it as conducive to citizenship. Indeed, by contrasting Hebrew with "the idiom of this country," he

${ }^{42}$ Ronald Schechter, "Rationalizing the Enlightenment: Postmodernism and Theories of Anti-Semitism," Historical Reflections/Réflexions historiques 25 (Summer 1999): 281-306. Republished in Daniel Gordon, ed., Postmodernism and the Enlightenment: New Perspectives in Eighteenth-Century French Intellectual History (London and New York: Routledge, 2001), 93-116. 
suggested that Jews were even better suited to the new republican ideal of citizenship than those whose means of communicating had been corrupted by civilization. Moreover, by reminding his readers that Hebrew was a "sacred" language, he both guaranteed the authenticity of the coronation odes and appealed to another characteristic of the nascent anti-rationalist nationalism: the sacralization of the nation. ${ }^{43}$

Whether he was celebrating a coronation, praying for the dauphin's health, arguing for mercantile rights or even writing a novel with a Jewish theme, Israel Bernard de Valabrègue played the role of the agent. He defended the Jews and Judaism, for the sake of his coreligionists as well as himself. Achieving these goals required cultural translation. Not only did Valabrègue serve as "interpreter of oriental languages" at the Royal Library, he interpreted Judaism for the surrounding gentile society. This entailed presenting the Jews and their religion as compatible with contemporary notions of citizenship, even as the latter were unstable or self-contradictory. Yet it would be misleading to reduce Valabrègue to a crafty spin-master. A closer reading of Valabrègue's writings and actions reveals an individual struggling to construct a personal identity.

\footnotetext{
${ }^{43}$ On the sacralization of the nation see Mona Ozouf, Festivals and the French Revolution, trans. Alan Sheridan (Cambridge, MA and London: Harvard University Press, 262-82; and Bell, Cult of the Nation, passim.
} 
The Arab merchant Aben-Zaïd in Lettres orientales and the anonymous milord of the Lettre each provide an apparently objective optic through which to view Valabrègue's much-maligned people and their religion. Aben Zaïd looks to Jewish tradition for edifying tales and is happy to report similarities between the Targum Sheni and "our divine Alcoran," and the apologist for Valabrègue and his merchant colleagues adopts the disinterested pose of a curious English milord assessing the utility of the Jews and the morality of their creed. More than rhetorical devices, however, Aben-Zaïd and the milord represent Valabrègue's own ambivalence about commerce. Aben-Zaïd expresses "regret" for "the time I am forced to give to my commerce," preferring the life the scholar, and the milord, though defending the utility of commerce, has retired from this occupation for the life of the gentleman-scholar. Valabrègue comes from a group that values learning as the highest form of activity but has had to justify its presence, to say nothing of providing its own subsistence, by commerce.

Like that of many of his gentile contemporaries, moreover, Valabrègue's ambivalence about commerce was informed by doubts about the benefits of civilization. The Jews were the "pegs and nails that one uses in a great building, and which are necessary to join all of its parts," but the tower of Babel was also a great building and as such was an affront to God. Valabrègue reaped the benefits of civilization, trading in silk and lace amidst the "great buildings" of Paris, but despite his linguistic prowess, he saw the "primitive" language of his ancestors as morally superior to what he heard in the modern Babel. Like his protagonists, the Arab with contacts in Turkey and France and the well-traveled Englishman with a French correspondent, Valabrègue easily adopts the role of cosmopolitan, yet competing with his role as citizen of the world is his desire to 
be the citizen of a nation. Although nationalism was the wave of the future, it drew on myths of primitive antiquity and can be seen as a reaction to the modern forces of cosmopolitan capitalism.

Complicating his choice between cosmopolitanism and nationalism was Valabrègue's desire to belong to two nations: the Jewish and the French. Thus he anticipated, well before the Revolution, the paradigmatic dilemma of modern French Jewry. His assimilation of Louis XVI to Solomon, collapsing the distinction between the two anointed monarchs, was one way of addressing the problem. Yet there were distinct limits to his respect for the biblical king. Indeed, returning to the story of Tarnegol Bara, whose meaning to Valabrègue we can now better appreciate, it becomes clear that the author identified more with the humble hoopoe and the remote bird-queen of Saba than with the magnificent king of Israel. Bound to Solomon's court, Tarnegol Bara nevertheless took leave without permission. His journey around the world "to see if I could not discover some country, province or kingdom that was unknown to Your Majesty, and which was not subject to your laws," can be taken in more than one sense. His wanderlust appears on the surface to be a cosmopolitan urge, and his survey of king's vast realm, like the description of subject nations in Psalm 72, suggests a glorification of empire. Yet the goal is to find a place that is not a subject nation. When he fails to find it he is prepared to commit suicide.

It turns out that such an Eldorado does exist, but a brief description reveals how unlike Solomon's kingdom it is. While Tarnegol Bara boasts of Solomon's "grandeur," "prudence," "wisdom," "riches," "beauty," "science," and power, his hoopoe friend trumps him with a description of his homeland. There, in "the most beautiful climate in 
the world," gold and silver are "more common than dust," which is a way of saying that they are of no importance to the inhabitants. Consequently, there was no war, not even the word for it. This primitive Eden boasted trees as old as the world and "the water of terrestrial Paradise." Even the queen reflected the primeval character of her realm, her feathers and bird feet marking her connection to nature. She was "one of the wonders of the world, for her beauty, her grace, her charms, her wisdom," but not, evidently, for her "science." That was the preserve of Solomon, who moreover only consented to impregnate her after she was sheared of her link to the primitive.

Given his misgivings about modernity, Valabrègue likely sympathized with the forcibly domesticated queen of Saba. An even closer identification appears between him and Tarnegol Bara. Both are servants of a king. Both are liminal figures, the bird crossing the threshold between animal and human, the man crossing multiple borders: between the Papal enclave and the French Kingdom, the world of Jewish tradition and the realm of secular Enlightenment, the library and the market, the land of France and the wider habitat of the cosmopolitan. Both bird and man also transgress the boundaries of subjecthood and agency.

Yet such was the condition of many persons, Jews and gentiles, in eighteenthcentury Paris. Historians have taken the famed corporate nature of Old Regime society too literally, whether studying the Jews or some other "community," as if it took 1789 to create the modern individual. Though Valabrègue was unusual in many respects, as a border-crosser he was not alone. How many other men and women shared the experience of the "agent" who navigated between different social categories, longed for an integrated community but not enough to forego the freedom that the modern world provided long 
before the French Revolution. Paradoxically, then, the free agent itself, or at least the agent attempting to be free - is a social category that historians and other students of the human experience should take seriously when trying to understand those who otherwise fall through the conceptual cracks. 